\title{
The Evaluation of Effectiveness of Reciprocal Teaching Strategies on Comprehension of Expository Texts
}

\author{
Gulhiz Pilten \\ Correspondence: Gulhiz Pilten, Department of Primary Teacher Education, Necmettin Erbakan University, Turkey.
}

Received: August 8, 2016

doi:10.11114/jets.v4i10.1791
Accepted: August 22, $2016 \quad$ Online Published: September 18, 2016

URL:http://dx.doi.org/10.11114/jets.v4i10.1791

\begin{abstract}
The purpose of the present research is investigating the effects of reciprocal teaching in comprehending expository texts. The research was designed with mixed method. The quantitative dimension of the present research was designed in accordance with pre-test-post-test control group experiment model. The quantitative dimension of the present research was designed in accordance with descriptive case study. The work group of the present research consists of 54 students of a primary school in the Konya province in 2014-2015. Reading Comprehension Evaluation Scale was developed by the researcher and implemented as pre-test and post-test on the work-group. Teacher / students interview forms were used for collecting qualitative data. At the end of 11-week teaching process, expository text comprehension skills of experiment group students, on who reciprocal teaching strategy was implemented, developed more than control group students, on who teaching process projected in the curriculum was implemented, at a statistically significant level.
\end{abstract}

Keywords: reciprocal teaching strategy, comprehension, expository texts

\section{Introduction}

Reading comprehension is one of the main linguistic skills students must acquire as of primary education level that requires inferring from a written material and comprehending the details (Rose et al., 2000).

Reading, which is defined as establishing and structuring the meaning in the related literature, is evaluated as an effective process that involves the stages of pre-reading, while-reading and post-reading stages within. Accordingly, effective readers should be able to use the reading comprehension skills at defined stages in order to structure the meaning (Akyol, 2006; Daly et al., 2005). Additionally, during the reading comprehension process, activities that require higher-order thinking, such as examining, choosing, decision-making, converting, interpreting, deferring, deduction, analysis, synthesis and evaluation should be conducted (Güneş, 2004). In this context, it can be claimed that strategies that develop comprehension should support the process of meaning structuring, and therefore cover the processes of students' mental structuring the text starting from pre-reading knowledge and experiences. Another important point in reading comprehension strategies is that the reader should be active during the process (Pressley, 2001). One of the many strategies that have the aforementioned qualities is reciprocal teaching.

\subsection{Reciprocal Teaching and Comprehension}

Reciprocal teaching strategy, developed by Palincsar and Brown (1984), is a systematic teaching activity that involves strategies that reinforce reading, such as predicting, clarifying, questioning and summarizing (Palincsar \& Brown, 1984). This teaching strategy enables students take a more active role in controlling and managing group dialogues, make them take on teachers' role in asking questions about the text, and this way load more meaning to the text at cognitive level (Pressley, 1998; Mastropieri \& Scruggs, 1997). The foundation of the approach is the assumption that knowledge and comprehension occur as a result of creative socializing that is formed through talks and negotiations between teachers and students or students and students (Palincsar \& Brown, 1984).

As stated above, reciprocal teaching strategy consists of four combined steps; questioning centred from the beginning to the end and reinforces reading comprehension. The first step is predicting. Here students make predictions related to the main and supporting ideas. Students make predictions about what can happen in the text making use of their previous knowledge and experiences. Additionally, as they read the text, they find the opportunities to evaluate their predictions and decide on the correction of these (King \& Johnson, 1999). The next step clarifying refers to students' making a critical evaluation of what they read (Palincsar \& Brown, 1984). At this step, students use meta-cognitive process to monitor their comprehension (King \& Johnson, 1999). In the other step, defined as questioning, students are reminded 
of the important information and focus on the main idea of the text by making them form questions about the text. In the final step, summarizing, students are expected to present what they comprehend from a part or whole of the text (Palincsar \& Brown, 1984; King \& Johnson, 1999). Reciprocal teaching strategy requires individual and group works throughout the lesson through asking and answering questions, modelling and setting examples (Raphael et al. 2003). Strategy is carried out by teachers' setting a model, rather than presenting, during teaching-learning process.

Brown and Palinscar (1986) have noted that reciprocal teaching is explained by three related theories of guided learning: Vygotsky's zone of proximal development (Vygotsky, 1978), Proleptic teaching (Wretsch \& Stone, 1976; Rogoff \& Gardner, 1984), and expert scaffolding (Wood et al. 1976).

Examination of the related literature shows that the effect of reciprocal teaching on reading comprehension is studied from many aspects. Findings of some of these studies are as follows:

Taylor and Frye (1992) define reciprocal teaching strategy as a strategy that requires students' monitoring their comprehension. In this context, many researchers take this strategy in terms of feeding and monitoring comprehension, therefore meta-cognition strategies (Hashey \& Connors, 2003; Hacker \&Tenet, 2002; Slater \& Horstman, 2002; Carter, 1997; Palincsar \& Brown, 1984; 1986; Palincsar \& Klenk, 1992). Among these, the findings of the study conducted by Carter (1997), who defined reciprocal teaching as self-monitoring skills in comprehension, revealed that reciprocal teaching developed reading comprehension and accordingly, it is important. According to this mention study, students don't only monitor themselves through this strategy, but they are also active participants of their own learning. Additionally, the findings of the study emphasize the effect on students' taking on teacher's role and interacting with their peers. This method allows students to take ownership over their reading and learning (Hashey \& Connors, 2003). By gaining control of their learning while they read, students also have the potential to become better self-regulators of their reading (Hacker \& Tenet, 2002).

According to Lysynchuck et al. (1990), students follow their instructors in many teaching activities, and take their instructors' reading comprehension strategies as models. This way, when they are given a teaching task, they can use these strategies with little help from their instructors. During this dialogue and modelling process, the instructorshould encourage students to ask questions of both the text and strategies. The instructor uses this dialogue to foster both reading comprehension and strategic cognition (Doolittle, et al. 2006).

Summarizing, clarifying, predicting and questioning, the components of reciprocal teaching strategy, are also known self-monitoring strategies. Combination of reading comprehension and self-monitoring provides many opportunities for teaching. In this method, not only do students monitor their own comprehension; they also become active participants in their learning and learn from others in the process. When students became the teacher and interacted with their peers, this too enhanced their comprehension (Carter, 1997). Especially questioning, which is one of the strategies used in reciprocal teaching and also one of the meta-cognitive skills, is among the variables of many researchers. Among these, Rosenshine et al., (1996) reported that students' forming questions related to the text enables them focus on the content of the text. This is important in terms of comprehension. That research found that during questioning through forming questions, students used some striking expressions and words in the text, their judgements on the main idea, question types and grammatical structures in the text. Another finding of that research is that reading activities conducted via questioning develop comprehension. King and Johnson (1999) defined the types of questions students used to develop comprehension and divided these into four as, questions directly related to the text, think and research questions, author and student interaction questions and independent questions. Researchers reported the positive effects of forming questions in those defined types on comprehending the expository texts.

Pearson and Fielding (1991) stated that reciprocal teaching was especially effective in developing comprehension among readers with low comprehension levels. It especially supported adequate decoders who comprehended poorly by providing an effective instructional procedure and increased their level of comprehension (Kelly et al. 1994; Klingner \& Vaughn, 1996; LeFevre et al. 2003). Westera and Moore (1995) studied the effects of teaching environments where reciprocal teaching is organized in different ways on poor readers and they investigated this on two experiment groups on which the approach was conducted in long-term and short-term periods, and one control group on which the approach wasn't conducted at all. According to their finding, there was a 95\% development in reading comprehension levels of the long-term experiment group, a 47\% development in short-term experiment group, and a $45 \%$ development in the control group.

In summary, research results emphasized the benefits of using reciprocal teaching in:

- Teaching students at different levels, and different subjects regardless of students' abilities (Myers, 2006);

- Helping students acquire vocabulary and reading comprehension for low-achievers in elementary grades (Todd \& Tracey, 2006; Pearson \& Fielding, 1991); 
- Developing students higher order thinking skills (Hacker \& Tenent, 2002).

\subsection{Expository Texts}

According to the related literature, expository texts used in the present research are defined as texts that inform about a topic or issue, transfer ideas and provide suggestions for the solution (Özdemir, 1998). The purpose of this kind of texts is transferring information. For this reason, expository texts are more functional, and beneficial in terms of providing information than narrative texts (Chenfeld, 1978).

Students enter school having a sense of narrative structures as they appear in texts. Across the years of school, their awareness of text structures must increase as they progressively shift from reading a story line or casual test to reading for information (Lorch \& Lorch, 1996). These texts are considered as more difficultly comprehended texts by students than narrative texts, as they include vocabulary items and content which aren't frequently used in daily life (Akyol, 2008; 2011; McCormick, 2007; Duke \& Kays, 1998).

No matter how difficult they are perceived, comprehending expository texts skills should be acquired by students. According to the related literature, comprehending expository texts is considered as one of the indicators of comprehending narrative texts and vocabulary knowledge. On the reading comprehension latent variable, comprehending narrative texts has .72, comprehending expository texts has .81 and vocabulary knowledge has .92 level significant effects (Yıldız, 2013).

Over the last decades, researchers have identified the difficulties students have while comprehending expository texts in intermediate elementary and beyond. McCormick (2007) listed six factors that make expository texts difficult to read, which were: text structure, new information, specialized vocabulary, readability level of text, abstract concepts and expectation that information should be retained by the reader. Similarly, Jennings et al. (2006) presented the challenges of expository text by comparing it to narrative texts. Specifically, they stated that expository texts are: less personal, more concept dense, contain more vocabulary and technical terms, require more background knowledge, and the reading level is often above students' frustration levels.

Many of the aforementioned difficulties can be eliminated by reciprocal teaching strategy including teacher modelling, peer interaction, questioning etc.

The purpose of the present research is investigating the effects of reciprocal teaching in comprehending expository texts. The present research is considered important for overcoming the problem of comprehending expository texts as stated in the related literature in terms of method proposition. Additionally, the present research, which adopted mixed method to explain the effect of this strategy which will be revealed through experimental method based on teacher and student remarks, is considered to contribute to the literature.

The problem statement of the present research was formed as "Does reciprocal teaching strategy has any effects on $4^{\text {th }}$ grade students' levels of comprehending expository texts?" In accordance with this purpose, the answers to the following questions are sought.

1. Is there any significant difference between reading comprehension pre-test and post-test scores of experiment group students, on who reciprocal teaching strategy was implemented, and control group students, on who the process projected in the curriculum continued in terms of;
a. intratextual understanding questions,
b. nontextual understanding questions,
c. intertextual understanding questions and,
d. total scores?

2. What are the ideas related to the effectiveness of the strategy of experiment group students, on who reciprocal teaching strategy was implemented?

3. What are the ideas related to the effectiveness of the strategy of experiment group teachers, who implemented reciprocal teaching strategy?

\section{Method}

\subsection{Research Design}

The present research, the purpose of which in investigating the effects of reciprocal teaching strategy on students' reading comprehension skills, employed mixed method. Mixed method assumes that research problems can be understood better using either quantitative or qualitative research approach alone, but using both together (Creswell \& Plano-Clark, 2007). The present research adopted the research design suggested by Steckler et al. (1992), which uses 
quantitative data to explain qualitative data (Figure 1).

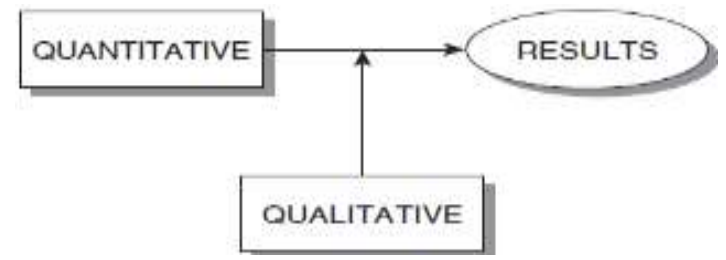

Figure 1. Research Design

The design presented in Figure 1 is implemented by successively adding the quantitative data obtained to present the effectiveness of reciprocal teaching strategy and the qualitative data collected in order to evaluate the effectiveness of the strategy from the perspectives of learners and teachers (Morse, 1991).

The quantitative dimension of the present research was designed in accordance with pre-test-post-test control group experiment model. The model can be defined as a design that provides the research with a highly statistical strength by testing the effect of experimental procedure on the dependant variable, enables the interpretation of the obtained findings in cause and effect context, and used frequently in behavioural sciences (Büyüköztürk, 2001). Table 1 presents the design used in the present research with symbols.

Table 1. Experimental design used in the present research

\begin{tabular}{llll}
\hline Groups & Pre-test & IndependentVariable & Post-test \\
\hline $\mathrm{G}_{\mathrm{E}}$ & RCES & X (Reciprocal Teaching Strategy) & RCES \\
& & 11 Weeks & $\mathrm{S}_{1} \mathrm{I}$ \\
& & $\mathrm{T}_{2} \mathrm{I}$ \\
\hline $\mathrm{G}_{\mathrm{C}}$ & RCES & $\begin{array}{l}\text { Process projected in the curriculum } \\
11 \text { Weeks }\end{array}$ & RCES \\
& & & \\
\hline
\end{tabular}

In Table $1, \mathrm{G}_{\mathrm{E}}$ refers to experiment group, $\mathrm{G}_{\mathrm{C}}$ refers to control group, RCES (Reading Comprehension Evaluation Scale) refers to pre-test and post-test measurements of experiment and control groups, $\mathrm{X}$ refers to the independent variable (reciprocal teaching strategy) implemented on experiment group subjects, $S_{1} I$ refers to interviews made with experiment group students after the experimental procedure, and $\mathrm{T}_{2} \mathrm{I}$ refers to interviews made with experiment group teachers after the experimental procedure. In addition, Table 1 shows that teaching activities conducted with experiment and control groups lasted for 11 weeks.

The quantitative dimension of the present research was designed in accordance with descriptive case study, which is a qualitative research method, as it enables a detailed investigation of an uncontrollable phenomenon or incident (Yıldırım \& Şimşek, 2005). In the present research, each of experiment group teacher and experiment group students were taken as an analysis unit.

\subsection{Participant Characteristics and Sampling Procedures}

The work group of the present research consists of 54 students, who studied in two $4^{\text {th }}$ grade classes of a primary schools in Meram central district of the Konya province in 2014-2015 spring semester, and the teacher of experiment group. Of these students 26 formed the experiment group, and 28 formed the control group. The school and classes of the students, who formed the work group, were selected among primary schools in Konya province, Meram district, via easily accessible sampling method.

The present research was conducted in the stated province and district in order to form an easily accessible work group so that the research was conducted faster and more economically (Yıldırım \& Şimşek, 2005). As a pre-study for determining the equivalence of experiment and control groups, researcher received ideas from teachers and principals, based on their ideas. It was decided that stated students of two $4^{\text {th }}$ grade classes of the selected school were equivalent in terms of Turkish lesson achievement and socio-economic levels. Experiment and control groups were selected within these classes through random sampling method. Data on some features of these groups are presented in Table 2 below.

Table 2. Characteristics of experiment and control groups

\begin{tabular}{|c|c|c|c|c|c|c|c|c|}
\hline \multirow[t]{4}{*}{ Groups } & \multicolumn{4}{|c|}{ Teacher Features } & \multicolumn{4}{|c|}{ Student Features } \\
\hline & \multirow[t]{3}{*}{ Gender } & \multirow{3}{*}{$\begin{array}{l}\text { Type of School } \\
\text { of Graduation }\end{array}$} & \multirow{3}{*}{$\begin{array}{l}\text { Length } \\
\text { of } \\
\text { Service }\end{array}$} & \multirow{3}{*}{$\begin{array}{l}\text { Length of } \\
\text { Service in the } \\
\text { Selected Class }\end{array}$} & \multicolumn{4}{|c|}{ Gender } \\
\hline & & & & & \multicolumn{2}{|c|}{ Female } & \multicolumn{2}{|c|}{ Male } \\
\hline & & & & & f & $\%$ & $\mathrm{f}$ & $\%$ \\
\hline Experiment & Female & $\begin{array}{l}\text { Faculty } \\
\text { Education }\end{array}$ & 15 years & 4years & 15 & 57,69 & 11 & 42,31 \\
\hline Control & Female & $\begin{array}{l}\text { Faculty } \\
\text { Education }\end{array}$ & 17years & 4years & 16 & 57,14 & 12 & 42,86 \\
\hline
\end{tabular}


As presented in Table 2, teachers of experiment and control group classes were equivalent in terms of gender, type of school they graduated from, and the length of service in their classes, while their total length of service in teaching profession is very close. Additionally, as presented in Table 2, the distributions of experiment and control group students by gender were similar.

Reading Comprehension Evaluation Scale (RCES) was applied as pre- and post-test to all students of experiment and control groups stated above $(\mathrm{n}=54)$ ). For this purpose it was given 40 minutes for each form of RCES (Form A and Form B). In addition, interviews were conducted with experiment group students to determine the opinions related with the effectiveness of the implications $(n=26)$. Experiment group teachers opinions were also taken after the experimental process.

\subsection{Data Collection Tools}

Reading Comprehension Evaluation Scale (RCES): Reading Comprehension Evaluation Scale, which was developed by the researcher and implemented as pre-test and post-test on the work-group, consists of 2 expository texts from a primary school Turkish lesson course book, which was approved by the Ministry of National Education and not used in the classes of the work group, and intratextual understanding questions (4 items for each text), nontextual understanding questions ( 3 items for each text) and intertextual understanding questions ( 3 items for each text) on these two texts. The scoring of the scale was organized in accordance with open-ended questions scoring key developed by NJDE (2014). Accordingly, a student can get a minimum score of 0 and a maximum score of 4 on each question. The total score from the scale ranges between 0 and 80. The scale consists of two sessions for each text as "Form A" and "Form B" and 10 questions for each text. For each session, students were provided with 40 minutes time.

While developing the scale, first a trial form was created, and it was implemented on 141 students, who had the similar features with the work group $\left(4^{\text {th }}\right.$ graders, studying in the same district and province, studying with the same teachers as of $1^{\text {st }}$ grade). Data collected from the trial implementation were scores in accordance with the open-ended questions scoring key mentioned above by the researcher, 3 classroom teachers and 1 assessment and evaluation expert, the total of 5 experts.

After this step, in order to test the consistency between scorings by different scorers (inter-rater reliability), Kendall W test was utilized and the analysis results are presented in Table 3.

Table 3. Reliability analysis on the consistency between scorings by different experts

\begin{tabular}{llllllllll}
\hline $\begin{array}{l}\text { Form/ } \\
\text { Item } \\
\text { No }\end{array}$ & ItemType & $\begin{array}{l}\text { Kendall } \\
\mathrm{W}\end{array}$ & $\mathrm{N}$ & $\mathrm{p}$ & $\begin{array}{l}\text { Form/ } \\
\text { ItemNo }\end{array}$ & ItemType & $\begin{array}{l}\text { Kendall } \\
\mathrm{W}\end{array}$ & $\mathrm{N}$ & $\mathrm{P}$ \\
\hline $\mathrm{A} / 1$ & Intratextual & 1.00 & 5 & 0.00 & $\mathrm{~B} / 1$ & Intratextual & 1.00 & 5 & 0.00 \\
$\mathrm{~A} / 2$ & Intratextual & 0.96 & 5 & 0.00 & $\mathrm{~B} / 2$ & Intratextual & 1.00 & 5 & 0.00 \\
$\mathrm{~A} / 3$ & Intratextual & 1.00 & 5 & 0.00 & $\mathrm{~B} / 3$ & Intratextual & 1.00 & 5 & 0.00 \\
$\mathrm{~A} / 4$ & Intratextual & 1.00 & 5 & 0.00 & $\mathrm{~B} / 4$ & Intratextual & 1.00 & 5 & 0.00 \\
$\mathrm{~A} / 5$ & Nontextual & 0.94 & 5 & 0.00 & $\mathrm{~B} / 5$ & Nontextual & 0.95 & 5 & 0.00 \\
$\mathrm{~A} / 6$ & Nontextual & 0.93 & 5 & 0.00 & $\mathrm{~B} / 6$ & Nontextual & 1.00 & 5 & 0.00 \\
$\mathrm{~A} / 7$ & Nontextual & 0.88 & 5 & 0.00 & $\mathrm{~B} / 7$ & Nontextual & 0,93 & 5 & 0.00 \\
$\mathrm{~A} / 8$ & Intertextual & 0.96 & 5 & 0.00 & $\mathrm{~B} / 8$ & Intertextual & 0.89 & 5 & 0.01 \\
$\mathrm{~A} / 9$ & Intertextual & 0.78 & 5 & 0.00 & $\mathrm{~B} / 9$ & Intertextual & 0.85 & 5 & 0.00 \\
$\mathrm{~A} / 10$ & Intertextual & 0.85 & 5 & 0.00 & $\mathrm{~B} / 10$ & Intertextual & 0.88 & 5 & 0.00 \\
\hline
\end{tabular}

As presented in Table 3, W coefficient for the scores given by experts for A and B Forms of RCES is statistically significant, which indicates that there is a statistically significant consistency between scores given by different experts.

Second step taken for the scoring consistency was asking two of the 5 members of the expert group, selected randomly, was asked to score the data collected from RCES again one week later. The purpose of this procedure was defining the consistency within the scorers (intra-rater reliability). Pearson product-moment correlation was calculated in order to define the correlation between first and second scoring of two raters, and the findings are presented in Table 4 .

Table 4. Reliability analysis for intra-rater consistency

\begin{tabular}{lll}
\hline & Expert 1(Scoring 2) & Expert 2(Scoring 2) \\
\hline Expert 1(Scoring 1) & 0,93 & \\
\hline Expert 2(Scoring 1) & & 0,89 \\
\hline
\end{tabular}

As presented in Table 4, Pearson correlation coefficient for the Expert 1's two scorings was 0.93, and it was 0.89 for Expert 2.For a scale to be accepted as reliable, calculated correlation coefficient should be 0.70 at least (Turgut, 1997). Therefore, this scale is reliable in terms of intra-rater consistency. The purpose of these procedures was presenting any mistakes that could be resulted from the scorers.

In addition, in order to test the reliability of the scale, test-re-test method was implemented and to test the stability of the 
scale in time. For this purpose, the scale was implemented on the same group after 3 weeks, and the correlation between two implementations was calculated as 0.87 . Accordingly, the scale is reliable in terms of mistakes that can be resulted from time (Turgut, 1997).

Both forms of RCES (Form A and Form B) consists of equal texts of the same genre, and similarly constructed items, and both forms are accepted as parallel, in order to reveal any mistakes that can be resulted from the forms, the correlations between the scores that students got from each form, and Pearson product-moment correlation coefficient that presents this correlation was calculated as 0.79 . Taken this coefficient, there is a consistency between parallel forms of the scale, and therefore, the scale is also reliable in this context (Turgut, 1997).

Finally, Cronbach alpha internal consistency coefficient was calculated in order to define the effect of any mistakes that can be resulted from scale items. This coefficient was calculated as 0.90 , which indicates the consistency between the items forming the scale.

In order to text content validity of the scale, Lawshe technique was utilized (Lawshe, 1975). The questions were presented to the an expert group consisting of 1 assessment and evaluation scale, 3 faculty members and 6 classroom teachers, and each item was graded as "item measures the targeted construct and is necessary", "item is related with the construct but irrelevant" or "item cannot measure the targeted construct" by these experts. Using the obtained data, content validity ratio (CVR) was calculated for each item. CVR calculated for each item was over 0.62, which is reported as valid by 10 experts in the related literature. Therefore, all items of the scale presented content validity. Additionally, the average of all items' CVRs was taken, and this was also above 0.62 , which indicated that the scale also presented content validity.

Teacher interview form: Semi-structured form developed by the researcher in order to define the effectiveness of reciprocal teaching strategy from teachers' perspectives consists of three main dimensions as; (1) evaluation of pre-teaching activities; (2) evaluation of while-teaching activities; and (3) evaluation of post-teaching (comprehension) activities, and 9 questions. Experiment group teacher was asked to explain the strengths and weaknesses of the strategy for each dimension, and analyse the classroom atmosphere, learning-teaching situations, teacher and student roles during the stated dimension. After interview form draft was examined by two faculty members of Necmettin Erbakan University, Department of Classroom Teaching, the questions were re-organized. Before the interview, date and time of the interview was set with the experiment group teacher; and she was informed about the purpose of the interview, interview duration and the issues that needed attention during interview. With the participant's approval, interview was recorded with a tape recorder, and after the interview data were organized in order to prevent data loss. The interview was conducted after experimental procedure and lasted almost 45 minutes.

Student interview form: Semi-structured form developed by the researcher in order to define the effectiveness of reciprocal teaching strategy from students' $(\mathrm{n}=26)$ perspectives consists of 3 questions that require students to express what kind of difficulties and/or convenience they experienced during the implementation process of the strategy, to compare this strategy with their regular teaching activities, and to evaluate the activities in terms of reading comprehension. For this purpose, an interview form draft was developed. After interview form draft was examined by two faculty members of Necmettin Erbakan University, Division of Classroom Teaching, the questions were re-organized. Before the interview, date and time of the interview, experiment group students were informed about the purpose of the interview, interview duration and the issues that needed attention during interview. With the parental approval, interviews were recorded with a tape recorder, and after the interview data were organized in order to prevent data loss. To ask for the approval, letters were sent to participants' parents. These letters consisted of 2 pages. $1^{\text {st }}$ page included information about the purpose, importance of the interview, interview questions, and how the collected data would be used, and the $2^{\text {nd }}$ page included a printed approval form for the parents to sign. Interviews were done after receiving approval from all parents, and the experimental procedure was completed. Interviews were conducted in participants' own classrooms, face-to-face. During the interviews, some measurements, such as preventing anyone entering the classroom, placing the tape recorder in a place not to disturb students, were taken to prevent any disturbances that might distract students. Each interview lasted for almost 15 minutes, and all were completed in 2 weeks.

\subsection{Data Analysis}

Quantitative data were analysed on SPSS 19.0 packaged software. In order to decide on the statistical technique to be used, whether the data collected from the dependent variable (RCES) met normality was tested with Kolmogorov-Smirnov normality test ( $p>.05$ ). According to the test results, scores obtained from both scales presented normal distribution, and the researcher decided to use dependant and independent samples t-tests, which are parametric hypothesis tests.

Qualitative data collected through interviews were analysed via descriptive analysis method. The main factor for selecting the descriptive analysis method was that conceptual construct related to the research question could be 
presented more clearly through this means (Yıldırım \& Şimşek, 2005). During data coding process, researcher studied the collected data and tried to divide these data into meaningful part and find out what each part meant conceptually. These parts, which presented a meaningful consistency within, were named by the researcher. This way, while coding a part among the collected data, the researcher tried to find a concept that could best describe the meaning of that part. The present research adopted "coding in accordance with concepts adopted from data" type, because the related literature didn't include any coding list related to the research subject.

\subsection{Experimental Manipulations or Interventions}

During reading activities conducted with the experiment group for 11 weeks, the following process was conducted for the total of 8 expository texts (Palincsar \& Brown, 1984).

1) The teacher described the 4 stages of the strategy for the students. In this step, students were provided with a written prompt worksheet that included what they were expected to do for each stage of the strategy (Oczkus, 2003). At the end of this step, the teacher checked whether all students were informed about the strategy, and completed any missing points. This step was conducted only once.

2) A reading activity in accordance with the strategy was carried out by the teacher. In this sample implementation, the teacher tried to set a model for all stages of the process by reading the text and thinking aloud. This model forming step was repeated at the beginning of every week.

3) The teacher made students take the responsibilities required by the strategy gradually every week, such as taking the teacher of leader role, developing the prompt-system projected by the strategy, and planning the exchanges in teacher and leader roles.

4) For each reading text, students worked in small groups of 4-5 members.

5) For each reading text, students took on the roles of the leader and participants in turn in their small groups.

6) The leader students read the text aloud, and the others listened.

7) The leader student took on the role of the teacher, and was asked to manage the discussions related to the stages of the reciprocal teaching strategy. At this step, the leader student was asked to stop reading after reading one part of the text, and use the questions types on the prompt card they had for the discussion to be held (Figure 2 and Figure 3).

\begin{tabular}{|c|c|}
\hline \multirow[t]{2}{*}{ Clarifying } & What does......... mean? \\
\hline & What is .........? \\
\hline Questioning & Who or what is the text about? \\
\hline \multirow[t]{2}{*}{ (Teacher questions) } & What do we know about........? \\
\hline & What are prompts given about .........? \\
\hline \multirow[t]{3}{*}{ Summarizing } & What is the main idea of the text? \\
\hline & What is the text mostly about? \\
\hline & $\begin{array}{l}\text { What does the information provided in the text mean } \\
\text { to you? }\end{array}$ \\
\hline Predicting & What can the rest of the text be about? \\
\hline \multicolumn{2}{|r|}{ Figure 2. Front face of prompt cards } \\
\hline \multicolumn{2}{|r|}{ LEADER } \\
\hline \multicolumn{2}{|c|}{$\begin{array}{l}\text { - Ask group members } 1 \text { or } 2 \text { questions, the answers of which are in the text } \\
\text { - First ask the question, than let a volunteer to answer. } \\
\text { - Ask other group members to ask questions. } \\
\text { - The questions you prepare should be about the How and Why of a case. } \\
\text { - Avoid Yes/No questions. }\end{array}$} \\
\hline
\end{tabular}

Figure 3. Back face of prompt cards 
8) Other group members (participants) were made to fill in the prompt cards presented in Figure 4.

\begin{tabular}{lc}
\hline & What do we know about the text? \\
\hline Predicting & Questioning \\
\hline Clarifying & Summarizing \\
\hline
\end{tabular}

Figure 4. Participant prompt cards

9) The teacher walked among the groups as they carried out the reading activities. In each group, she listened to group leader's questions and provided feedback. Additionally, she took the participant role in each group and answered leader's questions when it's her turn.

\section{Findings and Interpretations}

In this part, findings related to collected quantitative and qualitative data are studied separately in relation to the sub-problems.

\subsection{Comparison between Experiment Group and Control Group Students on RCES Pre-and Post-test Results}

Collected quantitative data were used to answer the first sub-problem of the research "Are the significant differences between reading comprehension scale pre-test and post-test scores of the experiment group students, on who reciprocal teaching strategy was implemented and the control group students, on who the process projected in the curriculum was conducted, in terms of; (a) intratextual understanding questions; (b) nontextual understanding questions; (c) intertextual understanding questions and (d) total scores?"

With this purpose, first in order to test whether there were statistically significant differences between the experiment and control groups in terms of comprehending expository texts skills before the experimental procedure, independent samples t-test was conducted on the reading comprehension evaluation scale (RCES) pre-test scores and the findings are presented in Table 5.

Table 5. T-Test Analysis Results on the RCES Pre-Test Scores of Experiment and Control Group Students

\begin{tabular}{llllllll}
\hline Dimension & Group & $\mathrm{N}$ & $\bar{X}$ & $\mathrm{~S}$ & $\mathrm{sd}$ & $\mathrm{t}$ & $\mathrm{p}$ \\
\hline Intratextual Understanding & Experiment & 26 & 19.69 & 1.67 & \multirow{2}{*}{52} & \multirow{2}{*}{1.04} & .305 \\
Scores & Control & 28 & 20.25 & 2.22 & & & \\
Nontextual Understanding & Experiment & 26 & 11.77 & 1.77 & \multirow{2}{*}{52} & .036 & .972 \\
Scores & Control & 28 & 11.75 & 2.14 & & & \\
Intertextual Understanding & Experiment & 26 & 5.12 & 1.63 & \multirow{2}{*}{52} & .088 & .930 \\
Scores & Control & 28 & 5.07 & 1.99 & & & \\
RCES Total Scores & Experiment & 26 & 36.58 & 3.18 & \multirow{2}{*}{52} & .557 & .530 \\
& Control & 28 & 37.07 & 3.33 & & \\
\hline
\end{tabular}

As presented in Table 5, there aren't any statistically significant differences between experiment and control groups' RCES pre-test scores, in terms of intratextual understanding scores $[t=1.04, p>05]$, in terms of nontextual understanding scores $[\mathrm{t}=.36, \mathrm{p}>.05]$, in terms of intertextual understanding scores $[\mathrm{t}=.88, \mathrm{p}>.05]$ and in terms of scale total scores $[t=.557, \mathrm{p}>.05]$. This finding indicates that there aren't any significant differences between groups in terms of comprehending expository texts skills. In other words, taken the RCES dimensions and scale total scores, groups are equivalent.

In order to test the changes in expository texts comprehending skills in experiment and control groups after 11-week experimental procedure, dependant samples t-test was used to compare RCES dimensions and total scores obtained before and after the experimental procedure (pre-test and post-test). Findings are presented in Table 6 and Table 7.

Table 6. T-Test Analysis Results on the RCES Dimensions and Scale Total Pre-Test and Post-Test Scores of Experiment Group Students

\begin{tabular}{|c|c|c|c|c|c|c|c|}
\hline Dimension & Test & $\mathrm{N}$ & $\bar{X}$ & S & sd & $\mathrm{t}$ & $\mathrm{p}$ \\
\hline Intratextual Understanding & Pre-test & & 19.69 & 1.67 & & & \\
\hline Scores & Post-test & 26 & 29.23 & 1.99 & 25 & 29.83 & .000 \\
\hline NontextualUnderstanding & Pre-test & & 11.77 & 1.77 & & & \\
\hline Scores & Post-test & 26 & 18.65 & 2.41 & 25 & 22.92 & .000 \\
\hline Intertextual Understanding & Pre-test & 26 & 5.12 & 1.63 & 25 & 3703 & 000 \\
\hline Scores & Post-test & 20 & 20.73 & 1.19 & 25 & 31.93 & .000 \\
\hline RCES Total Scores & $\begin{array}{l}\text { Pre-test } \\
\text { Post-test }\end{array}$ & 26 & $\begin{array}{c}36.58 \\
68.62\end{array}$ & $\begin{array}{l}3.18 \\
3.9\end{array}$ & 25 & 39.26 & .000 \\
\hline
\end{tabular}

As presented in Table 6, post-test score averages of experiment group students are higher than their pre-test scores for all dimensions and scale total of RCES. According to data presented in Table 6, there are statistically significant differences between pre-test and post-test scores of experiment groups in all dimension and scale total $[\mathrm{t}=29,83, \mathrm{p}<.05$; 
$\mathrm{t}=22,92, \mathrm{p}<.05 ; \mathrm{t}=37,93, \mathrm{p}<.05 ; \mathrm{t}=39.26, \mathrm{p}<.05]$. In other words, there was a statistically significant increase in expository texts comprehension skills of experiment group students after the experimental procedure.

Table 7. T-Test Analysis Results on the RCES Dimensions and Scale Total Pre-Test and Post-Test Scores of Control Group Students

\begin{tabular}{|c|c|c|c|c|c|c|c|}
\hline Dimension & Test & $\mathrm{N}$ & $\bar{X}$ & $\mathrm{~S}$ & $\mathrm{Sd}$ & $\mathrm{t}$ & $\mathrm{p}$ \\
\hline Intratextual Understanding & Pre-test & & 20.25 & 2.22 & & & \\
\hline Scores & Post-test & 28 & 27.04 & 2.33 & 27 & 11.98 & .000 \\
\hline Nontextual Understanding & Pre-test & & 11.75 & 2.14 & & 887 & 000 \\
\hline Scores & Post-test & 28 & 15.5 & 2.53 & 27 & 8.87 & .000 \\
\hline Intertextual Understanding & Pre-test & 28 & 8.01 & 3.96 & 27 & 372 & 713 \\
\hline Scores & Post-test & 28 & 8.04 & 1.91 & 27 & .372 & .713 \\
\hline RCES Total Scores & $\begin{array}{l}\text { Pre-test } \\
\text { Post-test }\end{array}$ & 28 & $\begin{array}{c}40.03 \\
50.57\end{array}$ & $\begin{array}{l}3.41 \\
4.49\end{array}$ & 27 & 15.65 & .000 \\
\hline
\end{tabular}

As presented in Table 7, post-test score averages of control group students are higher than their pre-test scores for all dimensions and scale total of RCES. According to dependent samples t-test results, which show whether this increase in statistically significant, of these increases in the control group scores after the experimental procedure, the differences in "intratextual understanding scores", and "nontextual understanding scores" dimensions and RCES total scores are statistically significant $[\mathrm{t}=11.98, \mathrm{p}<.05 ; \mathrm{t}=8.87, \mathrm{p}<.05 ; \mathrm{t}=15,65, \mathrm{p}<.05]$. The increase in the "intertextual understanding scores" dimension is not statistically significant $[\mathrm{t}=.372, \mathrm{p}>.05]$. In other words, the activities conducted in accordance with curriculum on the control group during the experimental procedures developed students' comprehending expository texts, understanding in intratextual and nontextual questions during the comprehension process, however it didn't have a significant effect on their intertextual comprehension. However, even students didn't present a statistically significant development in the stated dimension, we can claim that activities projected in the curriculum also developed students' expository text comprehension skills considering their total scores.

By testing the difference between the pre-test scores, it was found that experiment and control group students were equal before the experimental process. Additionally, pre-test and post-test scores of both groups were compared and it was found that different teaching environments organized for them resulted in a statistically significant increase in the expository text comprehension skills. In order to find out, which of these teaching environment designs was more effective in these positive changes, the differences between experiment and control group students' post-test RCES dimensions and total scores were tested. Accordingly, independent samples t-test analysis was conducted and the findings are presented in Table 8.

Table 8. T-Test Analysis Results on the RCES Post-Test Scores of Experiment and Control Group Students

\begin{tabular}{llllllll}
\hline Dimension & Group & $\mathrm{N}$ & $\bar{X}$ & $\mathrm{~S}$ & $\mathrm{sd}$ & $\mathrm{t}$ & $\mathrm{p}$ \\
\hline Intratextual Understanding & Experiment & 26 & 29.23 & 1.99 & \multirow{2}{*}{52} & \multirow{2}{*}{3.709} & \multirow{2}{*}{.001} \\
Scores & Control & 28 & 27.04 & 2.33 & & & \\
Nontextual Understanding & Experiment & 26 & 18.65 & 2.40 & \multirow{2}{*}{52} & 4.691 & .000 \\
Scores & Control & 28 & 15.5 & 2.53 & & & \\
Intertextual Understanding & Experiment & 26 & 20.73 & 1.19 & \multirow{2}{*}{52} & 25.11 & .000 \\
SCORES & Control & 28 & 8.18 & 2.28 & & & \\
RCES Total Scores & Experiment & 26 & 68.62 & 3.9 & \multirow{2}{*}{52} & 15.89 & .000 \\
& Control & 28 & 50.71 & 4.34 & & & \\
\hline
\end{tabular}

As presented in Table 8, post-test scores of experiment group students are higher than control group students in all RCES dimensions and total scores. According to t-test scores, conducted in order to find out whether these differences between the scores of both groups were statistically significant, the differences in the increases in the post-test scores of experiment and control groups are statistically significant in terms of all dimensions and total score in favour of experiment group [t=3.709, $\mathrm{p}<.05 ; \mathrm{t}=4.691, \mathrm{p}<.05 ; \mathrm{t}=25.11, \mathrm{p}<.05 ; \mathrm{t}=15.89, \mathrm{p}<.05]$. In other words, at the end of 11-week teaching process, expository text comprehension skills of experiment group students, on who reciprocal teaching strategy was implemented, developed more than control group students, on who teaching process projected in the curriculum was implemented, at a statistically significant level.

\subsection{Findings and Interpretations Related to Qualitative Data}

Collected qualitative data were used to answer the second and third sub-problems of the research; "What are the ideas related to the effectiveness of the strategy of experiment group students, on who reciprocal teaching strategy was implemented?" and "What are the ideas related to the effectiveness of the strategy of experiment group teacher, who implemented reciprocal teaching strategy?"

\subsubsection{Findings and Interpretations Related to Student Opinions}

Opinions of experiment group students, who were asked to evaluate the reciprocal teaching strategy after the 
experimental procedure, comparing it with other activities in terms of comprehending expository texts, are presented in Table 9.

Table 9. Experiment group students' opinions on whether the strategy is effective in comprehending expository texts

\begin{tabular}{lll}
\hline Category & F & $\%$ \\
\hline More effective & 22 & 84.62 \\
Lesseffective & 3 & 11.54 \\
No difference & 1 & 3.84 \\
\hline
\end{tabular}

As presented in Table 9, most of the experiment group students $(84.62 \%)$ think that reciprocal teaching strategy is more effective than comprehending expository texts activities they did before. Additionally, Table 9 shows that, only 3 of the students think the strategy is less effective (11.54\%), while only 1 stated that there were no differences $(3.84 \%)$. In order to explain these findings, students were asked about the positive and negative aspects and to evaluate the reciprocal teaching strategy considering the activities they normally did. Experiment students' opinions on this are presented in Table 10.

Table 10. Experiment group students' opinions on the comparison of reciprocal teaching strategy with their previous experiences

\begin{tabular}{|c|c|c|c|c|c|c|c|c|}
\hline Category 1: & & & Category 2: & & & Category 3: & & \\
\hline Comparison & $\mathrm{f}$ & $\%$ & Explanation & $\mathrm{f}$ & $\%$ & Detail & $\mathrm{f}$ & $\%$ \\
\hline \multirow[t]{9}{*}{ Positive } & \multirow[t]{9}{*}{19} & \multirow[t]{9}{*}{73,08} & \multirow[t]{3}{*}{ Easy } & \multirow[t]{3}{*}{8} & \multirow{3}{*}{42.11} & Peer support & 3 & 37.5 \\
\hline & & & & & & Extra time & 2 & 25 \\
\hline & & & & & & Guidance & 3 & 37.5 \\
\hline & & & \multirow[t]{3}{*}{ Effective } & \multirow[t]{3}{*}{6} & \multirow{3}{*}{31.58} & Quick comprehension & 1 & 16.67 \\
\hline & & & & & & Better comprehension & 4 & 66.66 \\
\hline & & & & & & Motivation & 1 & 16.67 \\
\hline & & & \multirow[t]{3}{*}{ Fun } & \multirow[t]{3}{*}{5} & \multirow{3}{*}{26.31} & Group work & 3 & 60 \\
\hline & & & & & & Moving in the classroom & 1 & 20 \\
\hline & & & & & & Teacher role & 1 & 20 \\
\hline \multirow[t]{4}{*}{ Negative } & \multirow[t]{4}{*}{7} & \multirow[t]{4}{*}{26,92} & Complicated & 2 & 28.57 & Too manystages & 2 & 100 \\
\hline & & & \multirow[t]{2}{*}{ Difficult } & \multirow[t]{2}{*}{4} & \multirow{2}{*}{57,14} & Finding questions & 3 & 75 \\
\hline & & & & & & Leadership role & 1 & 25 \\
\hline & & & $\begin{array}{l}\text { Time } \\
\text { consuming }\end{array}$ & 1 & 14.29 & Too much time & 1 & 100 \\
\hline
\end{tabular}

As presented in Table10, 19 of 26 students (73.08\%) evaluated the reciprocal teaching strategy in comprehending expository texts more positively compared to other activities they did their previous experiences. Of these 19 students, 8 stated positive ideas as they believed the strategy was easily applied (42.11\%), 6 believed it was effective (31.58\%), and 5 thought it was fun $(26.31 \%)$.

Of the 8 students, who stated positive ideas related to the easy implementation of the strategy, 3 of them stated that they believed so because the strategy provided peer-support (37.5\%), 2 because of the extra time allocated to activities (25\%), and 3 stated that they believed the strategy was easy because of the guidance provided due to structure of the strategy (37.5\%). In accordance with these findings, some of the ideas stated by the students are as follows:

"I get bored when we have to study with this kind of texts in the course book. It feels complicated for me. With this method, it is easier because I don't have to work alone. We studied with friends."

"I am not expected to read and understand in an instant, we have more time, so I can understand better."

"Everything we should do is already written on the sheet we are provided. We now have less work to do."

Of the 6 students, who stated positive ideas related to the effectiveness of the strategy, 4of them stated that they believed so because the strategy enabled them understand better (66.66\%), 1because they could understand faster (16.67\%) and 1 stated that they believed the strategy was effective because of the increased motivation (16.67\%). In accordance with these findings, some of the ideas stated by the students are as follows:

"I believe I can understand better than before, I can understand this type of stories better than before. And I don't think I will forget. A lot of information."

"Before this strategy, I could understand this kind of texts only after I read them 3-4 times. Now I can understand with just once."

"In this method, I feel excited when we start a new text. I want to start immediately and work with friends."

Of the 5 students, who stated positive ideas related to the fun side of the strategy, 3 (60\%) of them stated that they 
believed so because the strategy required group work, $1(20 \%)$ because of the role teacher takes on and $1(20 \%)$ stated that they believed the strategy was fun because they could move around the classroom during activities. In accordance with these findings, some of the ideas stated by the students are as follows:

"Reading with friends is more fun than reading by myself; I get bored when I have to read this type of texts alone. But it is fun with others. However, it would be more fun if could form groups with the friends we want."

"I can stand up while reading if I want. We can change places. It is not just reading, we do a lot of things."

"The teacher helps us as we read. She comes near us when we need help. She provides prompts. It is better than reading on our own."

As presented in Table 10, 7 of 26 students (26.92\%) evaluated the reciprocal teaching strategy in comprehending expository texts negatively compared to other activities they did their previous experiences. Of these 7 students, 4 stated negative ideas as they believed the strategy was difficult (57.14\%), 2 believed it was complicated (28.57\%), and 1 thought it was time consuming (26.31\%).

Of the 4 students, who stated negative ideas related to the difficulty of the strategy, 3 of them stated that they believed so because it was difficult to find questions (75\%), and 1 stated that they believed the strategy was difficult because of the leadership role they should take (25\%). In accordance with these findings, some of the ideas stated by the students are as follows:

"When it was our turn, I had difficulty in finding questions to ask. It is ok when it is others who ask the questions, but when it is me, it is difficult. Before, we used to read, and either the teacher asked the questions, or we answered the questions in the book. It was better that way."

"It is difficult to act like the teacher. We are not teachers, but students. The teacher is older, and also she graduated from university."

All of the students, who emphasized the complexity of the implementation, stated that the strategy was complex because there were too many stages to follow. In accordance with these findings, some of the ideas stated by the students are as follows:

"Before the strategy, we used to read the text once or twice, and it would be over. Now, it takes forever. I think it was better before."

"What we do is complicated, it is not clear, who does what. I don't think we can get used to it."

Statement of one student, who thought too much time was allocated for the strategy" is as follows:

"It really takes too long. Within this time, we could actually read 5-10 texts. One text takes more than a class hour. We shouldn't work this much on the same thing. Both I and the teacher are tired."

\subsubsection{Findings and Interpretations Related to Teacher's Opinions}

Evaluations of the experiment group teacher, who implemented reciprocal teaching strategy on her classroom for 11 weeks with 7 expository texts, on the effectiveness of the strategy are presented in Table 11, under the headings of evaluations of pre-teaching activities, evaluation of while-teaching activities and evaluation of post-teaching activities.

Table 11. Experiment group teachers' ideas related to the strategy

\begin{tabular}{lll}
\hline Process & Positive Ideas & Negative Ideas \\
\hline Pre-teaching & Setting model & Teaching of the strategy \\
While-teaching & Working in small groups & \\
& Student-student interaction & \\
& Student-teacher interaction & \\
& Setting model & \\
& Feedback & \\
& Students' responsibility for writing questions \\
& Student motivation & \\
Post-teaching & Comprehension & \\
& Remembering &
\end{tabular}

As presented in Table 11, experiment group teacher had problems only during teaching the strategy. According to teachers' statements, this difficulty teacher had during pre-teaching activities, continued during while-teaching to some extent. In addition, teacher's setting a model eliminated this difficulty at a great extent. Some of the teacher's statements according to these findings are as follows:

".... While implementing the strategy, the greatest difficulty I had was students' failure in understanding the strategy. Actually, I was prepared to teach it. However, it felt a little complicated at first. However, my implementing the strategy 
serving as a model enabled students to understand. As this process was repeated in the following weeks, all students could understand it. In other words, me repeating this teaching at the beginnings of the weeks, and especially serving as a model, enabled the students to understand. At the end everyone understood. After all, they weren't used to the process. Before the procedure, I used to ask a few questions before reading about the subject, that was all."

As presented in Table 11, experiment group teacher mostly placed positive emphasis on the while-teaching activities of the strategy. The teacher stated that, the strategy affected comprehension positively, as it required working in small groups, peer and teacher-students interaction, peer model, feedback, responsibility of writing questions and additionally provided student motivation. Some of the teacher's statements according to these findings are as follows:

"... Working in small groups was beneficial. I couldn't monitor comprehension of every student in the old system. Now, considering that there are 5-6 groups in the class, I can reach every one of them. I intervene if they experience any problems. Students can also discuss within their groups, as there aren't many members. In this context, they also set models for each other. However, I think the greatest benefit of the strategy is that, students have to write their own questions. Actually, we used to write questions with students before, but the questions didn't vary that much then. At first, they had difficulty in writing questions. After all, they were used to read then answer questions. But later, they got used to it. They also produced very good questions. Additionally, I felt that my students were excited to start new texts. I think the strategy drew their attention."

Finally, the experiment group teacher, who was asked to evaluate post-teaching process, stated that after the implementation of the strategy, students comprehended better, and remembered the texts (Table 11). Some of the teacher's statements according to these findings are as follows:

"I believe my students can comprehend expository texts better this way. Some of my students are not good at reading. I observed that they could understand better compared to previous teachings. I also have several students, who were mid-level at reading, who also showed improvements. The ones that were good improved even more. However, what made me happy most was that the students who were good were more interested. When I asked question about the text in the following lesson, all students remembered, which a new development was also. One of the greatest problems, which I don't experience with narratives, is that expository texts are difficult for students. When they had to study with this kind of texts, they used to frown. This method is different for them. They were really happy. I am going to use this method from now on."

\section{Conclusions and Discussion}

In the present research, which investigated the effects of reciprocal teaching strategy on $4^{\text {th }}$ grade students' comprehending expository texts, reciprocal teaching strategy was implemented in the experiment group for 11 weeks, and the process projected in the curriculum was implemented on the control group. Conclusions obtained from the measurements taken during the experimental process are as follows:

\subsection{Conclusions and Discussions Obtained from Quantitative Data}

According to the findings obtained from the Reading Comprehension Evaluation Scale (RCES) pre-test implementation, there aren't any statistically significant differences between experiment and control group students in terms of scale dimensions (intratextual understanding, nontextual understanding, intertextual understanding) and scale total scores. In other words, control and experiment group students were equal in terms of comprehending expository texts skill, before the experimental procedure.

In order to find out whether reciprocal teaching strategy implemented on experiment group students was effective on this group's comprehension of expository texts, their pre-test and post-test RCES all dimensions (intratextual understanding, nontextual understanding, intertextual understanding) and scale total scores were compared, and it was found that there was a significant difference in favour of post-test scores. In other words, reciprocal teaching strategy developed experiment group students' comprehending expository texts skills.

In order to find out the effectiveness of reading and comprehension activities projected in the curriculum on control group students' comprehending expository texts skills, their pre-test and post-test RCES all dimensions (intratextual understanding, nontextual understanding, intertextual understanding) and scale total scores were compared, and it was found that there were significant differences in "intratextual understanding questions", "nontextual understanding questions" dimensions and scale total scores, in favour of post-test scores. There wasn't a statistically significant difference between pre-test and post-test scores in terms of "intertextual understanding questions" dimension. In other words, the activities conducted in accordance with curriculum, i.e. the activities in the course book developed control group students' comprehending expository texts and understanding intratextual understanding and nontextual understanding questions during the comprehension process, however it didn't have the same significant effect on answering intertextual understanding questions. 
Another finding of the present research was that, experiment group students presented more improvement in all dimension of RCES (intratextual understanding, nontextual understanding, intertextual understanding) and total test scores than control group students at a statistically significant level. In other words, reciprocal teaching strategy implemented on experiment groups was more effective in comprehending expository texts than activities projected in the curriculum, which were carried out with control group students.

The findings of the present research related to the quantitative dimension, presented above, are in agreement with other studies in the related literature (Fung et al., 2003; Le Fevre et al., 2003; Carter, 1997; Palincsar \& Brown, 1984). Previous studies in the literature also reported that reciprocal teaching strategy developed reading comprehension; therefore it is beneficial from this aspect. Teacher and student reviews were used in order to define the positive effects found in the present research, and findings obtained accordingly are presented under the heading of conclusions and discussions obtained from qualitative data.

\subsection{Conclusions and Discussions Obtained from Qualitative Data}

According to experiment group students' statements on the effectiveness of the strategy on comprehending expository texts, most of the students think that the strategy is most effective than comprehension activities they encountered in their past experiences (projected in the curriculum). Students think so, because they believe it is easier due to peer support, constant guidance and extra time provided for comprehension; effective because it enables better and quicker comprehension and motivates students; and fun because it allows moving around during the activities andalso teacher provides positive contributions.

Findings related to experiment group teacher's ideas are in agreement with these findings related to student ideas. Experiment group teacher stated that working in small groups, student-student / teacher-student interaction and her setting the model affected students' comprehension positively. She also stated that she could provide feedback more easily while working with groups. Fung et al. (2003), Le Fevre et al. (2003), Aarnoutse and Brand-Gruwel (1997) and Palincsar and Brown (1984) also reported the positive effects of reciprocal teaching environment organized with small groups of 5-10 students on comprehension. At this point, student-student (peer) interaction is considered important (Hashey \& Connors, 2003; Palinscar et al., 1987). Additionally, according to related literature, one of the main reasons for the effectiveness of the strategy is teacher and student dialogues (Daly et al. 2005; Hacker \& Tenent, 2002; Palicsar $\&$ Brown, 1984; Kelly et al, 1994). This way, teachers can provide students with correct, on-time and reliable feedback, and students can establish connections using this feedback (King \& Johnson, 1999; Billingsley \& Ferro - Almeida, 1993).

Another finding reported in the literature, which is in agreement with the related finding of the present research is that, teacher's setting model, affects understanding positively. Students need to internalize the strategy they use to comprehend what they read (Duffy, 2002). From this aspect, teacher's setting a model is beneficial for students during the teaching of strategy directly. Students can only acquire self-regulation skills required by this strategy this way (King \& Johnson, 1999).

Additionally, very few of the students stated that reciprocal teaching in comprehending expository texts was less effective than the activities they encountered in their previous experiences. These students expressed negative ideas about the strategy, because they thought the strategy was complicated because it involved too many stages; difficult because of writing questions and leadership role; and also time consuming.

An interesting finding of the present research is that, unlike students, their teacher stated that the most important point in the effectiveness of the strategy was that students needed to write questions. Similar studies in the related literature reported similar findings. Rosenshine et al. (1996) claimed that students' responsibility of writing questions during the implementation of the strategy led them to pay more attention on the content of the text. This affects comprehension positively. They also mentioned the positive effects of scanning the texts with the purpose of writing questions on comprehension. Moreover, writing question activities make students more active and participating, and involved in the process while reading.

Other than writing questions, none of the negative ideas expressed by experiment group students were repeated by their teacher. Indeed, almost all of the students, who presented negative ideas, emphasized on the implementation process of the strategy. These students think that the implementation process is difficult, complicated and time-consuming. Therefore, it can be claimed that reading comprehension factor doesn't have any effects on students' negative evaluations of the strategy. In addition, when those students, who expressed negative ideas about the strategy, were asked "What would you say if you evaluate the strategy in terms of reading comprehension", most of them stated that they comprehended better with reciprocal reading strategy. Similarly, very few of the students who presented positive ideas laid emphasis on comprehension factor. For most of them as well, implementation process was the focal point of their evaluations. 
Unlike her students, experiment group teacher stated that the strategy affected the comprehension of some of her students she defined as weak positively. This statement of the teacher is in agreement with the findings of many researches in the literature (LeFevre et al., 2003; Westera \& Moore, 1995; Pearson \& Fielding, 1991). The teacher thinks that some of the students she defined as medium level also developed in terms of comprehension with the strategy. This statement is also in agreement with the related literature (Lysynchuck et al., 1990; Westera \& Moore, 1995). Additionally, according to teacher's expressions, the students, who she defined as good, also comprehended better and there was also a significant increase in motivation and interest among these students compared to previous implementations. Motivation and interest stated here, can also be found in student ideas, and is a case categorized as motivation, and there are similar findings presented in the related literature (LeFevre et al., 2003). It was found that, one of the main reasons in the improvements in comprehension was the development in remembering skills developed through strategy. Indeed, research findings show that one of the important contributions of the strategy to comprehension process is the development in remembering skills (Kelly et al., 1994). These evaluations on the comprehension achievement provided by the teacher explain the finding obtained with quantitative data that the strategy has a statistically significant effect on reading comprehension.

Finally, experiment group teacher stated that comprehension of expository texts by students was more difficult than narrative texts. These findings of the teacher are considered as correct and sound (Akyol, 2008; 2011; Duke \& Kays, 1998). Besides, the teacher stated that she would use the reciprocal teaching strategy in her further studies, especially with expository texts, which indicated the effectiveness on the strategy on this kind of texts. The findings reported in the literature that the strategy increase student achievement in comprehension expository texts by increasing their interests and motivations, are in agreement with the ideas of the teacher (LeFevre et al., 2003).

This study explored the effects of reciprocal teaching strategy on only reading comprehension skills of a group of 4th grade students from an urban school, has implications for research as well in that it would be worthwhile to expand this study to include students from different grades, across rural and urban areas. It would be beneficial to expand this study to the effects on other components of reading (vocabulary, high order thinking etc.). While reciprocal teaching utilizes four strategies: (1) predicting, (2) clarifying, (3) summarizing, and (4) questioning as a packaged intervention, the current and previous research has not addressed which of the four strategies is most effective in increasing reading comprehension abilities. A possible future study could investigate how each strategy in isolation or in varying combinations impacts reading comprehension growth in students. Finally, texts from other genres can also be explored; this might help to further determine the effectiveness of reciprocal teaching strategies in promoting and sustaining interest in literature study. Repeating the study over a longer period and incorporating different techniques, such as computer-assisted learning, story-sharing, graphic organizers, or tape-assisted teaching is also recommended.

\section{References}

Aarnoutse, C., \& Brand-Gruwel, S. (1997). Improving reading comprehension strategies through listening.Educational Studies, 23(2), 209-228. http://dx.doi.org/10.1080/0305569970230205

Akyol, H. (2006). Türkçe İlk-Okuma Yazmä̈ğretimi (YeniProgramaUygun). Ankara: PegemAkademiYayınc1lı.

Akyol, H. (2008). TürkçeÖğretimYöntemleri. Ankara: KökYayıncılık.

Akyol, H. (2011). YeniProgramaUygunTürkçeÖğretimYöntemleri. Ankara: PegemAkademiYayıncılık.

Billingsley, B., \& Ferro-Almeida, S. (1993). Strategies that facilitate readingcomprehension strategies in reading and listening settings.ReadingandWritingQuarterly, 9, 263-278. http://dx.doi.org/10.1080/1057356930090305

Büyüköztürk, Ş. (2001).DeneyselDesenler. PegemaYayınc1lık.Ankara.

Carter, C. (1997). Why reciprocal teaching? Educational Leadership, 54(6), 64.

Chenfeld, M. B. (1978). Teaching Language Arts Creatively. Harcourt Brace Javonavich, Inc.

Creswell, J. W., \& Plano-Clark, V. L. (2007). Designing and conducting mixed methods research. Thousand Oaks, CA: SAGE Publications.

Daly, E. J., Chafouleas, S., \& Skinner, C. H. (2005). Interventions for reading problems: Designing and evaluating effective strategies. New York: Guilford Press.

Doolittle, P. E., Hicks, D., Triplett, C. Nichols, W. D., \& Young, C. A. (2006). Reciprocal teaching for reading comprehension in higher education: A strategy for fostering the deeper understanding of the texts. International Journal of Teaching and Learning in Higher Education, 17(2), 106-118.

Duffy, G. D. (2002). The case for direct explanation of strategies. In C. C. Block, \& M. Pressley (Eds.), Comprehension instruction: Research-based best practices (pp. 28-41). New York: The Guilford Press. 
Duke, N., \& Kays, J. (1998). "Can i say 'Once upon a time'?": Kindergarten children developing knowledge of information book language. Early Childhood Research Quarterly, 13, 295-318. http://dx.doi.org/10.1016/S0885-2006(99)80041-6

Fung, I. Y., Wilkinson, I. A., \& Moore, D. W. (2003). L1-assisted reciprocal teaching to improve ESL students' comprehension of English expository text.Learning and Instruction, 13, 1-31. http://dx.doi.org/10.1016/S0959-4752(01)00033-0

Güneş, F. (2004). Okuma Yazma Öğretimive Beyin Teknolojisi, Ankara: Ocak Yay.

Hacker, D., \&Tenent, A. (2002). Implementing reciprocal teaching in the classroom: Overcoming obstacles and making modifications. Journal of Educational Psychology, 94(4), 699-718. http://dx.doi.org/10.1037/0022-0663.94.4.699

Hashey, M., \& Conners, D. (2003). Learn from our journey: Reciprocal teaching action research. The Reading Teacher, 57(3), 224-232.

Jennings, J. H., Caldwell, J., \& Lerner, J. W. (2006). Reading problems assessment and teaching strategies. (5th ed.). Boston: Pearson Education.

Kelly, M., Moore, D. W., \& Tuck, B. F. (1994). Reciprocal teaching in a regular primary school classroom. Journal of Educational Research, 88, 53-61. http://dx.doi.org/10.1080/00220671.1994.9944834

King, C. M., \& Johnson, L. M. (1999). Constructing meaning via reciprocal teaching. Reading Research and Instruction, 38(3), 169-186.http://dx.doi.org/10.1080/19388079909558287

Klingner, J. K., \& Vaughn, S. (1996). Reciprocal teaching of reading comprehension strategies for students with learning disabilities who use English as a second language. The Elementary School Journal, 96(3), 275. http://dx.doi.org/10.1086/461828

Lawshe, C. H. (1975). A quantitative approach to content validity. Personnel Psychology, 28, 563-575.

Le Fevre, D. M., Moore, D. W., \& Wilkinson, I. A. (2003). Tape-assisted reciprocal teaching: Cognitive bootstrapping for poor decoders. British Journal of Educational Psychology, 73, 73-78. http://dx.doi.org/10.1348/000709903762869905

Lorch, R. F., \& Lorch, E. P. (1996). Effects of organizational signals on free recall of expository text. Journal of Educational Psychology, 88(1), 38-48. http://dx.doi.org/10.1037/0022-0663.88.1.38

Lysynchuk, L. M., Pressley, M., \& Vye, N. J. (1990). Reciprocal teaching improves standardized reading comprehension performance in poor comprehenders. The Elementary School Journal, 90, 469-484.http://dx.doi.org/10.1086/461627

Mastropieri, M. A., \& Scruggs, T. E. (1997). Best Practices In Promoting Reading Comprehension In Students With Learning Disabilities, Remedial\& Special Education, 18, 197-216. http://dx.doi.org/10.1177/074193259701800402

McCormick, S. (2007). Instructing students who have literacy problems. (5th ed.). Upper Saddle River New Jersey: Pearson Merrill Prentice Hall.

Morse, J. M. (1991). Approaches to qualitative-quantitative methodological triangulation.Nursing Research, 40, 120-123. http://dx.doi.org/10.1097/00006199-199103000-00014

Myers, P. (2006). The princess storyteller, Clara Clarifier, Quincy Questioner, and the Wizard: reciprocal teaching adapted for kindergarten students. The Reading Teacher, 59(4), 48-57.

NJDE (2014). Guide to criterion-based holistic scoring: Science. New Jersey: New Jersey Department of Education

Oczkus, L. D. (2003). The four reciprocal teaching strategies. In Reciprocal teaching at work: Strategies for improving reading comprehension (pp. 13-28). Newark, DE: International Reading Association

Özdemir, E. (1998). Eleştirel Okuma. Ankara: ÜmitYayıncılık.

Palincsar, A. S., \& Brown, A. (1986).Interactive teaching to promote independent learning from texts.The Reading Teacher, 39, 771-777.

Palincsar, A. S., \& Brown, A. L. (1984). Reciprocal teaching of comprehension-fostering and comprehension-monitoring activities. Cognition and Instruction, 1, 117-175. http://dx.doi.org/10.1207/s1532690xci0102_1

Palincsar, A. S., \& Klenk, L. (1992). Fostering literacy learning in supportive contexts. Journal of Learning Disabilities, 25, 211-225. http://dx.doi.org/10.1177/002221949202500402 
Palincsar, A. S., Brown, A. L., \& Martin, S. (1987). Peer interaction in reading comprehension instruction. Educational Psychologist, 22(3), 231-253. http://dx.doi.org/10.1207/s15326985ep2203\&4_3

Pearson, P. D., \& Fielding, L. (1991). Comprehension instruction. In R. Barr, M. Kamil, P. Mosenthal, \& P. D. Pearson (Eds.), Handbook of reading research: Volume II (pp. 815-860). White Plains, NY: Longman Publishing.

Pressley, M. (1998). Comprehension strategies instruction. In J. Osborn \& F. Lehr (Eds.), Literacy for all: Issues in teaching and learning, language arts \& disciplines. New York: Guilford.

Pressley, M. (2001). Comprehension instruction: What makes sense now, what might make sense soon. Reading Online, $5(2)$.

Raphael, T. E., Johnston, M., Pocius, C., Highfield, K., Pentzien, K., Brimmer, K., \& George, M. (2003). Questioning practices in the classroom. In B. Guzzetti (Ed.), Literacy in America: An encyclopedia. Santa Barbara, CA: ABC-CLIO Publishers.

Rogoff, B., \& Gardner, W. P. (1984). Adult guidance of cognitive development. In B. Rogoff, \& J. Lave (Eds.). Everyday cognition: Its development in social context (pp. 134-157). London: Cambridge University Press.

Rose, D. S., Parks, M., Androes, K., \& McMahon, S. D. (2000). Imagery-based learning: Improving elementary students' reading comprehension with drama techniques. Journal of Educational Research, 94(1), 55-64. http://dx.doi.org/10.1080/00220670009598742

Rosenshine, B., Meister, C., \& Chapman, S. (1996). Teaching students to generate questions: A review of the intervention studies. Review of Educational Research, 66, 181-221. http://dx.doi.org/10.3102/00346543066002181

Slater, W. H., \& Horstman, F. R. (2002). Teaching reading and writing to struggling middle school and high school students: The case for reciprocal teaching. Preventing School Failure, 46, 163-166. http://dx.doi.org/10.1080/10459880209604416

Steckler, A., McLeroy, K. R., Goodman, R. M., Bird, S. T., \& McCormick, L. (1992). Toward integrating qualitative and quantitative methods: An introduction. Health Education Quarterly 19, 1-8. http://dx.doi.org/10.1177/109019819201900101

Taylor, B., \& Frye, B. (1992).Comprehension strategy instruction in the intermediategrades.Reading Research and Instruction, 32(1), 39-48. http://dx.doi.org/10.1080/19388079209558104

Todd, R. B., \& Tracey, C. H. (2006). Reciprocal teaching and comprehension: A single subject research study. Published master Thesis, Kean University, United States. Retrieved April 15, 2007, from http://www.eric.ed.gov

Turgut, F. (1997). Eğitimdeölçmevedeğerlendirmemetotları. Ankara: GülYayınevi.

Vygotsky, L. S. (1978). Mind in Society: The development of the higher psychological processes. Cambridge, MA: Harvard University Press.

Westera, J., \& Moore, D. (1995). Reciprocal teaching of reading comprehension in a New Zealand high school. Psychology in the Schools, 32(3), 225-232. http://dx.doi.org/10.1002/1520-6807(199507)32:3<225::AID-PITS2310320310>3.0.CO;2-F

Wood, D. J., Bruner, J. S., \& Ross, G. (1976). The role of tutoring in problem solving. Journal of Child Psychology and Psychiatry, 17,89-100. http://dx.doi.org/10.1111/j.1469-7610.1976.tb00381.x

Wretsch, J. V., \& Stone, C. A. (1976). A social interaction analysis of learning disabilities remediation. Paper presented at the International Conference of the Association for children with Learning Disabilities, San Francisco.

Yıldırım, A., \& Şimşek, H. (2005). Sosyalbilimlerdenitelaraştırmayöntemleri. Ankara: SeçkinYayıncılık.

Yıldız, M. (2013). Okuma Motivasyonu, Akıcı Okuma ve Okuduğunu Anlamanın Beşinci Sınıf Öğrencilerinin Akademik Başarılarındaki Rolü. Turkish Studies-International Periodical for the Languages, Literature and History of Turkish or Turkic, 8(4), 1461-1478.

This work is licensed under a Creative Commons Attribution 3.0 License. 